\title{
ORIGIN AND GENESIS OF ECLOGITES FROM THE EARTH'S MANTLE
}

\author{
Dorrit E. Jacob \\ Institut für Geologische Wissenschaften, Universität Greifswald, Germany
}

Ever since the first find of a diamondiferous eclogite in 1899 (Bonney, 1899), eclogite xenoliths from kimberlite pipes sparked scientific interest. Although quite rare (ca. 1\% of the lithosphere underneath Kaapvaal is eclogite, Schulze, 1989), they are the prominent host rocks for diamond and an ascertained member of the sublithospheric mantle underneath every craton. Their study allows insights into sublithospheric mantle composition, processes of craton formation and speculations on Archean geodynamics.

Of broadly basaltic to picritic bulk chemistry mantle eclogites are mineralogically diverse: most are bimineralic often rutile-bearing, but primary quartz or coesite, sanidine, apatite, zircon, olivine and orthopyroxene have been reported, too. The high aluminium suite contains kyanite and/or corundum and rare spinel-garnet rocks with or without corundum (alkremites, corganites and corgaspinites, e.g. Sobolev, 1977; Mazzonne and Haggerty, 1989) may be related to this group. The occurrence of diamond or graphite, however, is not linked to any specific eclogitic paragenesis.

Garnets in mantle eclogites are pyrope-grossularalmandine mixtures between approximately $\mathrm{Py}_{8} \mathrm{Alm}_{15} \mathrm{Gros}_{5}, \mathrm{Py}_{24} \mathrm{Alm}_{14} \mathrm{Gros}_{62}$ and $\mathrm{Py}_{26} \mathrm{Alm}_{6} \mathrm{Gros}_{15}$; eclogites with garnets with more than $50 \mathrm{~mol} \%$ grossular being termed grospydites (Sobolev, 1977). Clinopyroxenes are omphacitic with jadeite contents typically between 20 and $70 \mathrm{~mol} \%$. Often used classifications for mantle eclogites based on $\mathrm{MgO}$ in garnets or $\mathrm{Na}_{2} \mathrm{O}$ and $\mathrm{MgO}$ contents of the clinopyroxenes (Coleman et al., 1965; Shervais, 1988; Taylor and Neal, 1989) differentiate three groups of eclogites (A, B, C), all of which occur in each of the eclogite-bearing kimberlite pipes. High Al eclogites with kyanite and/or corundum are Group C, whereas Group A also incorporates pyroxenites. The latter may be distinguished from eclogites by their lower jadeite contents expressed in the relation of 6-fold coordinated Al to 4-fold coordinated Al (Aoki and Shiba, 1973), however, at low bulk Al-contents a line between these two rock types may sometimes be diffcult to draw. Trace element and isotopic studies show a very heterogeneous picture; trace elements may vary up to several hundred times chondritic values and extreme $\mathrm{Nd}$ isotopic variations between -22 to $+680 \varepsilon_{\mathrm{Nd}}$ (from Roberts Victor eclogites) are known, probably reflecting old age and accumulation of alteration processes (e.g. metasomatism) of some of the samples. As of yet, not many eclogites suites are dated. Archean isochron ages exist for eclogites from Roberts Victor (2.6 to $3.0 \mathrm{Ga}, \mathrm{Sm}-\mathrm{Nd}$, Re-Os; Jagoutz et al., 1984; Shirey et al., 2001), Udachnaya (2.6 to 2.9; Pb-Pb, ReOs; Jacob and Foley, 1999, Pearson et al., 1995) and Koidu (3.3 Ga, Barth, 2001), whereas model ages and zircon dating imply paleoproterozoic ages for the first few Canadian eclogites studied (Heaman et al., 2002, Jacob et al., this volume).

A large number of case studies have left us with apparently contradicting views on eclogite formation: models involving low-pressure origins as subducted oceanic crust or its residues, underplated basalts or lowpressure cumulates were put forward as well as models favouring high-pressure origins as upper mantle melts or cumulates and combinations of high- and lowpressure processes. Historically, models explaining mantle eclogites as high-pressure cumulates were the first to be put forward. These were mainly based on high pressure experiments in simplified basaltic systems in which garnet and clinopyroxene crystallized at about $3 \mathrm{GPa}$ (O'Hara and Yoder, 1967). Helmstaedt and Doig (1975) and Jagoutz et al. (1984) were the first to propose a subduction origin. Since then, the genesis of mantle eclogites was discussed between these two extrema. Today, however, it becomes increasingly clear that more genetic models than these two extrema have to be dicussed. Support for alternative models, as e.g. underplated basalts (E1 Fadili and Demaiffe, 1999) or as cumulates from various crustal pressures (Barth, 2002, Schmickler et al., submitted) have mainly come from trace elements whose analyses were much facilitated by the advent of the laser ablation ICP-MS in situ technique.

Nevertheless, models involving subducted oceanic crust are successful for a number of eclogite suites from the mantle, and oxygen isotopes are a powerful tool in tracing seawater alteration at low-pressure experienced by the eclogite precursors. An origin as oceanic crust or its residues has been put forward for eclogites from Africa (e.g. Roberts Victor, Bellsbank, Koidu) and Siberia (e.g. Udachnaya, Mir). Those eclogite suites show a range of $\delta^{18} \mathrm{O}$ values deviating from that of unchanged Earth's mantle but similar to those from 
ophiolites, the most extreme variations shown by eclogites from the Roberts Victor pipe. Evidence for a shallow origin is also based on trace element patterns: positive $\mathrm{Eu}$ and $\mathrm{Sr}$ anomalies together with flat heavy rare earth elements in reconstructed bulk rock trace element systematics are typical features inherited from plagioclase rich precursor rocks (i.e. gabbros), impossible to generate by melting peridotite at high pressures.

Kyanite eclogites, in turn, cannot coexist with peridotitic mantle, but would react with olivine to form garnets plus pyroxenes. These alumina-rich compositions can therefore not represent mantle derived material, but are compatible with derivations from metamorphosed low-pressure melts.

Also the subduction model was developped further over time, mainly because of the better accessibility of trace element characteristics, but also because of a better understanding of modern oceanic crust. In some eclogite suites it is now possible to differentiate between plagioclase-rich cumulate precursors and protoliths that were lavas (e.g. Jacob and Foley, 1999, Barth, 2001) and there is evidence that even oceanic cumulates (dunite, pyroxenites) may be present in kimberlite-borne xenolith suites (Foley et al., this volume).

The "mantle-origin" model, in turn, has not received as much attention lately and positive evidence for a highpressure origin of eclogite xenoliths is scarce at present. What are the geochemical characteristics of highpressure garnets and clinopyroxenes? Liquidus experiments in basaltic systems may be unrealistic, as they exeprimentally take low pressure melts to higher pressures, a process unlikely to happen in nature. Clearly, the role of compatible trace elements will be prominent in deciphering the different origins.

Using a forward-modelling approach the major element chemical compositions of a range of cumulates and melts from different parental compositions at variable pressures can be predicted and compared to eclogite compositions (Jacob et al., 2003, Schmickler et al., submitted). This method, in combination with compiled as well as unpublished major, trace element and isotopic data on eclogite xenoliths worldwide, yields clear constraints on the compatibility of the eclogite composition with the "mantle-origin" model.

\section{REFERENCES}

Aoki, K. and Shiba, I. (1973) Pyroxenes from lherzolite inclusions inclusions of Itinomegata, Japan. Lithos 6, 41-51.

Barth, M., Rudnick, R.L., Horn, I., McDonough, W.F., Spicuzza, M., Valley, J.W. and Haggerty, S.E., 2002. Geochemistry of xenolithic eclogites from West Africa, part II: Origins of the high $\mathrm{MgO}$ eclogites. Geochim. Cosmochim. Acta, 66: 4325-4345.

Bonney, T.G., 1899. The parent-rock of the diamond in South Africa. Geol. Mag., 6: 309-321.

Coleman, R.G., Lee, D.E., Beatty, L.B. and Brannock, W.W., 1965. Eclogites and eclogites: their differences and similarities. Geol. Soc. Am. Bull., 76: 483-508.

El Fadili, S. and Demaiffe, D., 1999. Petrology of eclogite and granulite nodules from the Mbuji Mayi kimberlites (Kasai, Congo): Significance of kyaniteomphacite intergrowths. In: J.J. Gurney, J.L. Gurney, M. Pascoe and S.H. Richardson (Editors), Proc. 7th International Kimberlite Conference. Red Roof Design cc, Cape Town, pp. 205-213.

Foley, S.F., Buhre, S., Jacob, D.E. and Rehfeldt, T., 2003. Dunite and pyroxenite xenoliths as metamorphosed cumulates from the Archean lower oceanic crust, this volume.

Jacob, D.E. and Foley, S.F., 1999. Evidence for Archean ocean crust with low high field strength element signature from diamondiferous eclogite xenoliths. Lithos, 48: 317-336.

Jacob, D.E., Schmickler, B. and Schulze, D.J. (2003): Trace element geochemistry of coesite- bearing eclogites from the Roberts Victor kimberlite, Kaapvaal craton. Lithos, Special Issue on the Two Cratons Workshop, in press.

Jagoutz, E., Dawson, J.B., Hoernes, S., Spettel, B. and Wänke, H., 1984. Anorthositic oceanic crust in the Archean Earth. 15th Lunar Planet. Sci. Conf.: 395396. (abs).

Schulze, D.J., 1989. Constraints on the abundance of eclogite in the upper mantle. J. Geophysical Research, 94(B4): 4205-4212.

Heaman, L.A., Creaser, R.A. and Cookenboo, H.O., 2002. Extreme enrichment of high field strength elements in Jericho eclogite xenoliths: a cryptic record of Paleoproterozoic subduction, partial melting, and metasomatism beneath the Slave Cracton, Canada. Geology, 30: 507-510. 
Helmstaedt, H. and Doig, R., 1975. Eclogite nodules from the Colorado plateau - samples of subducted Franciscan type oceanic lithosphere. Phys. Chem. Earth, 9: 95111.

Mazzonne, P. and Haggerty, S.E., 1989. Corganites and corgaspinites: two new types of aluminous assembalges from the Jagersfontein kimberlite pipe. Proc. 4th Internat. Kimberlite Conf. 795-808.

O'Hara, M.J. and Yoder, H.S., 1967. Formation and fractionation of basic magmas at high pressures. Scott. J. Geol., 3: 67-117.

Pearson, D.G., Snyder, G.A., Shirey, S.B., Taylor, L.A., Carlson, R.W. and Sobolev, N.V., 1995. Archaean ReOs age for Siberian eclogites and constraints on Archaean tectonics. Nature, 374: 711-713.

Schmickler, B., Jacob, D.E. and Foley, S.F. Eclogite xenoliths from the Kuruman kimberlites, South Africa: II Geochemical fingersprinting of cumulate processes in thick crust. Submitted zu Lithos, Special issue on trace element fingerprinting of geological processes, January 2003

Shervais, J.W., Taylor, L.A., Lugmair, G.W., Clayton, R.N., Mayeda, T.K. and Korotev, R., 1988. Early Proterozoic oceanic crust and the evolution of subcontinental mantle: eclogites and related rocks from southern Africa. Geol. Soc. Amer. Bull., 100: 411423.

Shirey, S.B., Carlson, R.W., Richardson, S.H., Menzies, A., Gurney, J.J., Pearson, D.G., Harris, J.W. and Wiechert, U., 2001. Archean emplacement of eclogitic components into the lithospheric mantle during formation of the Kaapvaal craton. Geophys. Res. Lett., 28(13): 2509-2512.

Sobolev, N.V., 1977. Deep-seated inclusions in kimberlites and the problem of the composition of the upper mantle. American Geophysical Union, Washington,D.C., 279 pp.

Taylor, L.A. and Neal, C.R., 1989. Eclogites with oceanic crustal and mantle signatures from the Bellsbank kimberlite, South Africa, part I: Mineralogy, petrography and whole rock chemistry. J. Geol., 97(5): 551-567.

Contact: DE Jacob, Institut für Geologische Wissenschaften, Universität Greifswald, F.L. Jahnstr. 17a, D-17487

Greifswald, Germany, E-mail: djacob@uni-greifswald.de 